\title{
The Effects of Analgesia-Sedation on the Immune System Before and After Cerebral Digital Subtraction Angiography
}

\author{
Serebral Dijital Subtraksiyon Anjiyografi Öncesi ve Sonrasu Analjezi- \\ Sedasyonun Immün Sistem Üzerine Etkileri
}

Ercan TURECI ${ }^{2}$, Osman KIZILKILIC ${ }^{1}$

${ }^{1}$ Istanbul University, Cerrahpasa Faculty of Medicine, Department of Radiology, Istanbul, Turkey

2Istanbul University, Cerrahpasa Faculty of Medicine, Department of Anesthesiology, Istanbul, Turkey

Correspondence address: Ercan TURECI / E-mail: etureci@yahoo.com

KEYWORDS: Angiography, Cerebrum, Cytokine, Inflammation, Lymphocytes, Immune system

ANAHTAR SÖZCÜKLER: Anjiyografi, Serebrum, Sitokin, Inflamasyon, Lenfosit, İmmün sistem

\section{Dear Editor}

We would like to report an erratum about our manuscript entitled "The Effects of Analgesia-Sedation on the Immune System Before and After Cerebral Digital Subtraction Angiography" DOI: 10.5137/1019-5149.JTN.4296-11.1 published in your journal.

There is one sentence with an error and one repeated sentence, which should be deleted.

In the results section on page 4, the following sentence should be as follows; Comparing the two groups with respect to lymphocytes after cerebral DSA showed that CD56 (independent sample t test; $p=0.00001$ ) and CD56 (independent sample $t$ test; $p=0.00001$ ) levels were significantly higher in patients received analgesia-sedation and other parameters did not show significant differences (independent sample t test; $\mathrm{p}<0.05$ ).

The correct form should be as; Comparing the two groups with respect to lymphocytes after cerebral DSA showed that
CD25 (independent sample $t$ test; $p=0.00001$ ) levels were significantly elevated and CD56 (independent sample t test; $p=0.00001$ ) levels were significantly decreased in patients who received analgesia-sedation while other parameters did not show significant differences (independent sample t test; $\mathrm{p}<0.05)$.

The following sentence should be deleted; In our study when we compared the levels of immune cells, in Group I (lack of sedation) level of CD40 and CD56 were significantly elevated, whereas other immune cells did not differ too much (Table $\mathrm{VI})$.

\section{REFERENCE}

1. Tureci E, Kizilkilic O, Akyol S, Pekel F, Tanriverdi T, Hanci M, Bahar M: The Effects of Analgesia-Sedation on the immune system before and after cerebral digital subtraction angiography. Turk Neurosurg 21(3):340-346, 2011. doi: 10.5137/10195149.JTN.4296-11.1. 